Marmara Üniversitesi Siyasal Bilimler Dergisi • Marmara University Journal of Political Science • Cilt 5, Özel Sayı, Nisan 20I7, ISSN 2147-6934, ss. I-I6•DOI: xxxx

\title{
Kuruluşundan Günümüze Karadeniz Ekonomik İşbirliği Örgütü
}

\begin{abstract}
Alaeddin YALÇINKAYA*
Öz

Karadeniz Ekonomik İşbirliği Örgütü (KEİ), Soğuk Savaş sonrası Türkiye’nin öncülüğünde kurulmuş olup kapsama alanı daha çok eski Doğu Bloku ülkeleridir. Bu örgütleşmede Karadeniz kıyısı ve hinterlandında eski Sosyalist sisteme mensup ülkelerin liberal düzene geçişinde uyarlama fonksiyonu öngörülmüştür. Bu kapsamda serbest pazar, katılımcı yönetim, hukukun üstünlügü ve insan haklarının ön planda tutulduğu bir işbirliği ve entegrasyon hedeflenmiştir. 1990'larda, Rusya Federasyonu’nun (RF) sıkıntılı döneminde kuruluşunu tamamlayan örgüt, daha bu aşamada özellikle kıyıdaş olmayan ülkelerin de üyeliğinde sorunlar yaşamıştır. Azerbaycan ve Arnavutluk’a karşın RF politikalarına yakın duran Ermenistan ve Yunanistan da örgüte kurucu üye olmuşlardır. Yunanistan, Bulgaristan ve Romanya aynı zamanda $\mathrm{AB}$ üyesi/üye adayı olduğu halde eski Sovyet cumhuriyetlerinin çoğu aynı zamanda BDT üyesi idi. Bu durum üyeler arasındaki ekonomik, sosyal ve hukuki altyapı uyumsuzluğuna yol açıp aynı zamanda örgütün gelişmesinde ve fonksiyonal hale gelmesinde önemli engel olarak kendisini göstermiştir. 2016 yılı itibariyle KEİ, üye ülkeler arasında düzenli toplantıların yapıldığı, diplomatik temasların gerçekleştiği bir zeminin ötesine pek fazla geçememiştir. Karadeniz bölgesi ve hinterlandı ülkeler olarak işbirliği ve asgari entegrasyon düzeninin kurulması bütün üyelerin çıkarına olduğu halde bölgesel çatışmalar ve ülkesel rekabetler, bu yöndeki örgütleşmeden beklenen sonuca ulaşmayı engellemiştir. Başta Azerbaycan-Ermenistan, Gürcistan-RF ve Ukrayna-RF olmak üzere komşular arasında daha çok sınır ve toprak konusuna dayanan çatışmaların barışçıl çözümünden sonra örgütün fonksiyonal hale gelmesi beklenebilir.
\end{abstract}

Anahtar kelimeler: Karadeniz Ekonomik İşbirliği Örgütü, Çatışma Çözümü, Sosyalist Sistem, Liberal Düzen, Fonksiyonalizm.

\section{Black Sea Economic Cooperation from the Establishment to Today}

\begin{abstract}
* Prof. Dr., Marmara Üniversitesi, Siyasal Bilgiler Fakültesi, Uluslararası İlişkiler Bölümü, alaeddin.yalcinkaya@marmara.edu.tr
\end{abstract}

Organization of the Black Sea Economic Cooperation (BSEC) is an organization established under Turkish leadership after the Cold War era, and its area of interests rests more among Eastern Bloc countries. It is one of the important function is guiding the transition to a liberal order for the former Socialist countries. In this context, free market, participantory democracy, respect for human rights 
are primarily targeted. This organization has established in the 1990s as the Russian Federation (RF) was in troubled, and even during this period non-litorial states membership was a contexted issue. Azerbaijan and Albania were accepted as the founding members in exchange for Russian backed Armenia and Greece. Althoug Greece, Bulgaria and Romania were members/candidate members of EU, most of these former Soviet republics were also Commonwealth of Independent States members. Thus, this caused economic, social and legal infrastructure mismatch among members hindering the institution's ability to become more efficient and functional. As of 2016, BSEC cannot still move beyond remaining permanent platform for diplomatic contacts by gathering its members regularly. Although Black Sea region and its hinterland need cooperation and integration among regional countries, yet due to conflicting interests, national competition and conflicts, blocked the desired result of organization in this direction. Finding peaceful and rightful solutions to territorial conflicts between members, such as Azerbaijan-Armenia, Georgia-RF and Ukraine-RF border and land issues, might make BSEC a more functional and meaningful regional organization.

Keywords: Organization of the Black Sea Economic Cooperation, Conflict Resolution, the Socialist System, the Liberal Order, Functionalism.

\section{Giriş}

II. Dünya Savaşı sonrasında uluslararası sistem önemli ölçüde Uluslararası Hukuk kuralları çerçevesine çekilirken bu süreç daha çok uluslararası örgütler üzerinden sağlanmıştır. Başta BM olmak üzere gittikçe artan sayıda bölgesel kapsamlı ekonomik işbirliği veya savunma amaçlı örgütler global politikaların oluşumunda önemli roller oynamıştır. Soğuk Savaş sonrasında uluslararası örgütleşmede yeni zeminler ortaya çıkmış, bunun yanında önceki örgütleşmeler günün şartlarına uygun hale getirilmiştir. Sovyetler Birliğinin çözülmesi sürecinde Varşova Paktı ile COMECON da dağılmış, bir süre sonra bunların yerine yerine Bağımsız Devletler Topluluğu (BDT), Kolektif Güvenlik Anlaşması Örgütü (KGAÖ), Avrasya Ekonomik Birliği (AEB), Şanghay İşbirliği Örgütü (ŞİÖ) gibi örgütler ortaya çıkmıştır.

Karadeniz Ekonomik İşbirliği Örgütü’nün (KEİ) kuruluş süreci tam da Sovyetler Birliği’nin dağılması ile birlikte başlamış ve 1998'de bu süreç tamamlanmıştır. 2012 itibariyle 20. yılını dolduran örgütün İstanbul'da o yıl düzenlenen toplantısı, önemli ölçüde durum değerlendirme zemini olmuştur ( Jusufovic, 2013).Bu anlamda Soğuk Savaş döneminin güvenlik politikaları ile ekonomi politikaları arasında doğal olarak varlığı sözkonusu olan ilişkiler gittikçe artan oranda ekonomik amaçlı uluslararası örgütler üzerinden etkinliğini hissettirmeye başlamıştır. Yeni dönemde ise önceki dönemin güvenlik riskleri sözkonusu olmadığından sayı ve eylem çerçevesi bakımından daha çok ekonomik kapsamlı uluslararası örgütlerde hızlı belki de biraz aceleci büyümeler izlenmiştir.

Başta eski Sovyet coğrafyası ve yakın bölgesi olmak üzere Afro-Avrasya’da Soğuk Savaş dönemi sonrasında yaşanan gelişmeler, uluslararası örgütlerin kapsadığı toplumların sosyo-ekonomik gerçeklerinin belki de fazla ilerisinde seyrettiğinden beklenen başarı henüz gerçekleşmemiştir. Burada sözkonusu sorun "sosyo-ekonomik yapıların mı yeni gelişmelere ayak uyduramadığı 
yoksa örneğin örgütleşmelerin aceleci programları mı olduğu, yani sözkonusu yapıyı dikkate alma gereği görmediği mi” konusu çok ta önemli değildir. Dönemin siyasal karar merciinde bulunanlar belki de devrimci bir ruhla önce örgütleşmeye gidip arkasından toplumların işbirliği ve entegrasyon sürecine mecbur bırakılmasını hedeflemiş olabilirler. Bunun yanında sınır çatışmaları, bölgesel çatışmalar, ekonomik krizler ve iç savaşlara kadar giden siyasal sorunlar, devletçi ekonomi sonrasında toplumların liberal düzene uyumunu engellemiştir. Öte yandan bölgenin hammadde ve pazar bakımından önemi ile jeopolitik zenginlikleri global güçlerin yoğun müdahalesine yol açmış ve bu durum Sovyet sonrasında doğal gelişimini engellemiştir. Kısaca bölge ülkelerinin yapısal gerçekleri ile bölgesel örgütleşme programı arasındaki ahenksizliğin varlığı sözkonusudur. Bu ahenksizliğin önemli ölçüde bölge dişı güçlerin kendi çıkarları doğrultusunda bölge politikalarını istikrarsızlaştırmalarından kaynaklanabiliyor olması ayrı bir konudur.

Bu bölümde KEİnin kuruluş süreci özetlenirken örgütün kuruluşundan günümüze yaşanan sorunların 2016 sonu itibariyle örgütten beklenen dinamizmin görülmemesinin nedenleri irdelenecektir. Örgütün kuruluş şartında belirtilen hedeflerin pek gerçekleşmemiş olması birincil tespit olarak çalışmanın konusudur. Karadeniz ve hinterlandında yaşanan bütün bölgesel veya ikili sorunlar ve çatışmalara karşın bölgenin işbirliğini zorunlu ve gerekli kılan ekonomik ve jeopolitik zenginliğine ve bu işbirliğinin önemine temas edilmektedir. Bu bağlamda başta Rusya Federasyonu (RF)-Türkiye ilişkileri olmak üzere KEİnin kuruluşundan günümüze örgütün işleyişini etkileyen ilişkiler ele alınmaktadır. 2016 itibariyle KEİnin bölgesel ve global politikalardaki yeri ve önemi ile bölgesel barış ve refah için bu örgüt kapsamında öneriler tartışılmaktadır.

\section{KEi’nin Kuruluş Süreci}

Soğuk Savaş’in sona ermesi ve SSCB'nin dağılması sürecinde Doğu Bloku ülkelerini kuşatan Varşova Paktı ve COMECON’un dağılması, bu örgütlerin kapsadığg ülkelerin yeni oluşumlarda yer alması için fırsat sunmuştur. Karadeniz kıyıdaşı olarak Romanya ve Bulgaristan, Varşova Paktı ve COMECON’un doğrudan üyeleri iken Moldova, Ukrayna, Rusya Federasyonu (RF) ve Gürcistan ile Karadeniz hinterlandında bulunan Azerbaycan ve Ermenistan SSCB'yi oluşturan cumhuriyetler olarak dolayısıyla sözkonusu örgütlere üye idiler. Buna karşın Karadeniz kıyıdaşı olup bu örgütlerde yer almayan tek ülke Türkiye'dir. Bununla beraber Karadeniz'e en uzun kıyısı olan ülke de Türkiye'dir. Doğu Bloku'nun çökmesi ile kapitalist dünyada bir bakıma ortada kalan bu komşular ile ortak çıkarlar etrafında örgütleşmeye gitmek konusunda Türkiye’nin öncü rol oynaması bu bakımdan anlamlıdır. Türkiye’nin kazan-kazan politikasıyla bölgesel örgütleşmede öncü girişimine karşın Karadeniz kıyıdaşı ve hinterlandındaki ülkeler arasında derin anlaşmazlıkar, hatta çatışmalar bulunmaktaydı. Bunların bir kısmı halen çözülmüş değildir. Bunun yanında ilk bakışta Karadeniz bölgesi dışında görünen birçok anlaşmazlık veya çatışma konusunun son tahlilde bölgedeki dengelerle ilgili olduğu görülmektedir (Sezer, 1996). 
KEİnin ekonomik temelli fonksiyonal ve Karadeniz bölgesi ve hinterlandı ile sinırlı bölgesel bir örgüt olma vasfı, özellikle II. Dünya Savaşı’ndan sonra sayıları artan birçok uluslararası örgütün paylaştığı özelliklerdendir. ${ }^{1}$ Bununla beraber global polititkalara yön veren "uluslararası ekonomi politik", şüphesiz burada da geçerliliğini korumaktadır. Başta ABD olmak üzere diğer batılı aktörlerin de arkasında bulunduğu KEİ’nin örgütleşme sürecinin öncüsü Türkiye’dir. Böyle bir örgütlenme ile eski devletçi ekonomik sisteme mensup ülkelerde liberal ekonomik düzenin kurumsallaşması hedeflenirken bu ülkelerin yeniden sosyalist veya benzeri devletçi bir düzene geri dönmelerinin önlenmesi temel hedefler arasındadır. En azından liberal ekonomik düzenin gelişmesi ile demokratikleşme süreci hızlanacak, bölgesel barış ve refah yanında insan hakları, hukukun üstünlüğü gibi konularda da iyileşme sağlanacaktı.

Sovyetleri Birliği'ni oluşturan cumhuriyetler 1990 yılı boyunca egemenliklerini ilan ederek bağımsızlık yolunda yumuşak adımlar atmışlar, 1991'de ise bağımsızlıklarını ilan etmişlerdir. 1991'in Aralık ayında yayınlanan Almatı (Alma Ata) Deklarasyonu ile BDT kurulurken bir anlamda SSCB’nin dağıldı̆̆ı ilan edilmiştir. KEİ sürecinde yer alan ülkelerin aynı bölgeyi paylaşan komşular olarak aralarında rekabet veya işbirliği sıklıkla yaşanmıştır. Birbiriyle bazen rekabet bazen işbirliği içinde olan aktörlerin faaliyet alanları ise daha çok siyasal, kültürel ve ekonomik konulardır (Mehmetcik, 2016: 38). 25 Haziran 1992'de İstanbul'da toplanan Arnavutluk, Azerbaycan, Bulgaristan, Ermenistan, Gürcistan, Moldova, Romanya, RF, Türkiye, Ukrayna ve Yunanistan devlet veya hükümet başkanları, Boğaziçi Belgesi’ni imzalayarak KEİnin kuruluş sürecini başlatmıştır. Bu belge ile imzacı ülke temsilcileri mal, hizmet, sermaye ve işgücünün serbest dolaşımı yönünde aralarında işbirliği yapmak ve gerekli koşulları oluşturmak istikametinde iradelerini ortaya koymuşlardır. ${ }^{2}$

Boğaziçi Belgesi ile imzacı devletler, öncelikle toplumlar arasında barışçı ve yapıcı ilişkilerin önemini vurgulayarak bu ilişkilerin gelişmesi yönünde kararlılıklarını dile getirmişlerdir. BM Şart ve AGİT prensipleri ışı̆̆ında imzacı tarafların çıkarlarını ön planda tutan bir örgütleşmenin bütün devletler için gerekli olduğu beyan edilmiştir. Bu çerçevede serbest pazar ekonomisinin

1 II. Dünya Savaşından sonra Batı Avrupa yaşananları açılkamada bir dereceye kadar başarılı olan fonksiyonalist yaklaşım, günümüzdeki gelişmeler açısından önemini kısmen yitirmiş olabilir. Bununla birlikte bu yaklaşım kısmen de olsa gelişmekte olan ülkeler arasındaki ilişkileri açıklayabilir durumdadır. Bu anlamda KEİ’nin kuruluş amaçları ve bu örgütten beklentiler açısından Fonksiyonalizm son derece önemlidir. http://www.worldlibrary.org/articles/ functionalism_(international_relations). Bu akımın öncüsü David Mitrany’ye göre devletler arasında entegrasyon ilişkileri ilerledikçe halklar, ihtiyaçlarının tedarikinin ulus aşırı işbirliğine dayandığını görecek ve bu yönde faydacı bir hesapla uluslararası örgütleşme düzenlemelerinin kendi menfaatlerine hizmet ettiğini fark edeceklerdir. Devlet sınırları arasındaki kapılar serbestleştikçe diğer ülkelere geçiş kolaylaşacak, daha az formalite ile diğer devletlerde iş kurulabilecek, iş-güç sahibi olunabilecek, iş aramaya gidilebilecektir. Eğitim, turizm, sağlık alanında da bütün bölge tek ülke haline gelecektir. Bir süre sonra ulus devlete bağllığın yerini işlevselci örgütler veya bu örgütlerin ilgili organları alacaktır. Ki bu yüzden özellikle az gelişmiş ülkelerin komşularıyla entegrasyon ilişkilerine girmeleri bir yana aralarında adeta duvar örmelerini zorunlu kılan genellikle sömürgeci dönemden birçok gerekçe bulunmakta veya yeni sömürge şartlarında suni çatışmalar çıkarılmaktadır.

2 http://www.bsec-organization.org/documents/declaration/summit/Reports/Istanbul1992.pdf Erişim tarihi: 08.11.2016, KEİnin kuruluş aşaması birçok örnekte olduğu gibi niyet sözleşmesi, ara sözleşmeler ve nihayet kuruluş anlaşmasının yürürlüğe girmesi sürecinden geçmiştir. Bu bağlamda 25 Haziran 1992 niyet beyanı sözleşmesi olup 5 Haziran 1998 Yalta Sözleşmesi ise kuruluş sözleşmesidir. 
geliştirilmesi yönünde altyapı oluşturulması için gerekli hukuki düzenlemeler yapılması zorunluluğu; demokrasi, hukukun üstünlüğü ve insan haklarına saygının işbirliğin temeli olması; işbirliği ile üye ülkeler arasında barış, istikrar ve refah istikametinde gelişmenin hızlandırılması; böylece bölgedeki etnik ve siyasi anlaşmazlıkların yol açtığ gerilimlerin yumuşatılmasına zemin oluşturulması; nihayet sözkonusu anlaşmazlıkarın barış içinde, bütün tarafları tatmin edebilecek yöntemlerle çözülmesi ile baskı, şiddet ve illegal hareketlere karşı birlikte mücadelenin gerekliliği kabul edilmiştir.

5 Haziran 1998 Yalta Zirve Deklarasyonu 1 Mayıs 1999’da yürürlüğe girmiştir. ${ }^{3}$ Boğaziçi belgesi ile başlayan süreç KEİ Şartı ile tamamlanarak girişimin tam örgüt olma vasfı tescil edilmiştir (Nureş, 1996). KEİ’nin en önemli organı devlet veya hükümet başkanlarından oluşan KEİ Zirvesidir. Bundan sonra KEİ Dışişleri Bakanları Konseyi en önemli karar organıdır (Karluk, 2014, 545). KEİ’nin belli başlı oganları olarak KEİ Uluslararası Daimi Sekreteryası, Dönem Başkanlığı, Üçlü Yönetim, KEİ Parlamenterler Meclisi, KEİ İş Meclisi, Karadeniz Ticaret ve Kalkınma Bankası, Çalışma Grubu, Uzmanlar Grubu, Vergi Grubu, konseyin yetkisi altında kurulan ve kurulacak olan komite ve hizmet birimleri olarak sayllabilir. ${ }^{4}$

\section{KEi’nin Kuruluş Sorunları}

KEİ’nin kuruluş belgelerinde örgüt üyelerinin diğer örgütlere (AB, BDT, ECO vb.) üyeliklerine itiraz edilmeyeceği bu bağlamda diğer örgütlere karşı yükümlülüklerinin sözkonusu olabileceği de Boğaziçi Deklarasyonu’nda belirtilmiştir. Böyle bir hüküm, örgüte üyeliği teşvik edici bir unsur olduğu gibi örgüt üyeliğinin anlamını zayıflatmaktadır. Kuruluş aşamasında özellikle RF’nun BDT coğrafyasında yeni bir örgütlenmeye pek istekli olmaması, bölge ülkelerinin olabildiğince örgüte üyeliklerinin sağlanması gibi gerekçeler, birçok açıdan örgüte üyelikle ilgili sınırlama getirilmesini önlemiştir.

Örgütün daha kuruluş aşamasında RF önderliğindeki BDT’na karşı bir girişim imajı veya tehdidi Moskova’yı sürekli meşgul etmiştir. Şüphesiz bu süreçte başta ABD olmak üzere batının böyle bir örgütlenmeyi yeniden sosyalizme dönüşü engelleyici bir araç olarak görmesinin etkisi sözkonusudur. BDT içerisinde ABD öncülüğünde Rusya’ya karşı oluşturulan GUAM ülkelerinin (Gürcistan, Ukrayna, Azerbaycan, Moldova) tamamı aynı zamanda KEİ’nin kurucu üyesi olması anlamlıdır. ${ }^{5}$

KEİnin kuruluş sürecindeki temel sorunu, her bir kurucu üyenin diğer bazı üyelerle sözkonusu olan sorunlarıdır ki bunların önemli bir kısmı 2016 yılı sonu itibariyle çözülememiş, hatta daha da derinleşmiştir. Örneğin AB’ye üyelikte öncelikle aday ülke ile diğerleri (diğer adaylar veya

3 Charter of the Organization of the Black Sea Economic Cooperation, http://www.bsec-organization.org/documents/ LegalDocuments/statutory/charter/Download/CHARTER\%20web\%20080630.pdf erişim tarihi: 10.11.2016

4 Charter of Organization of the Black Sea Economic Cooperation.

5 ABD öncülüğünde kurulan örgütün adı Organization of Democracy and Economic Development olup sekreteryası Kiev'de bulunmaktadır. http://guam-organization.org/en/node/422 Erişim tarihi: 10.11.2016 
mevcut üyeler) arasındaki siyasi sorunların çözümlenmiş olması gereği dikkate alındığında bir uluslararası örgütün üye yapısı ile başarısı arasındaki bağlantı daha net olarak görülebilir. Bu bağlamda her bir ülkenin diğeri/diğerleri ile kuruluş aşamasındaki sorunları ve 2016 sonu itibariyle gelinen aşamayı şöyle özetleyebiliriz:

KEİ’nin kuruluş sürecini önemli ölçüde Türkiye yönettiği halde bu örgütün coğrafi, nüfus, ekonomik, askeri vb. açılardan en büyük üyesi RF'dur. Varşova Paktı ve Sovyetler Birliği’nin dağılması ile Moskova ekseninden "kurtulan" diğer devletler, özellikle 1990’larda Rusya’nın yeniden etkisine girme endişesini, dış politik tercihlerde ön plana çıkarmışlardır. Azerbaycan ve Gürcistan’ın BDT üyeliği konusunda zikzakları bu endişenin sonucudur. 2017 başı itibariyle Gürcistan ve Ukrayna’nın BDT üyesi olmadığını belirtelim.

Gürcistan-Rusya ilişkilerinde geçen süre zarfında önemli olaylar yaşanmış ve iki ülke birbirinden daha fazla uzaklaşmıştır. 2008’de Gürcistan’nn iki özerk bölgesi Abhazya ve Güney Osetya’da başlayan olaylar üzerine yaşanan gelişmeler sonucu RF, BDT Barış Gücü adı altındaki birliklerle Gürcistan’a girmiştir. Başta ABD olmak üzere hiçbir ülkeden yardım alamayan ülke birkaç hafta boyunca tamamen Rus askerinin kontrolü altında kalmıştır. Belirtmek gerekir ki bu esnada ABD donanması Gürcistan’a yardım etmek istediği halde Montreux Boğazlar Sözleşmesi’nin ilgili maddeleri gereği (Karadeniz kıyıdaşı olmayan askeri gemiler Boğazlar'dan geçmeden 15 gün önce diplomatik tarik ile Türkiye’yi bilgilendirme şartı) Karadeniże geçememiştir. Bu müdahale sonucunda Abhazya ve Güney Osetya fiilen Gürcistan'dan ayrılarak, RF’nun desteği ile bağımsızlıklarını ilan etmişlerdir. RF’nun bütün baskı, tehdit, zaman zaman yaptırımlarına karşın Abhazya ve Güney Osetyàyı tanıyan ülke sayısı 2017 başı itibariyle beş civarında kalmıştır.

RF ile Ukrayna ilişkileri, bağımsızlığın ilk yıllarında çok daha iyi olup ilk BDT sözleşmesinin sadece RF, Ukrayna ve Beyaz Rusya arasında imzalandığını, RF’nun özellikle diğer cumhuriyetlerin "yükünü" taşımak istemediğini, bu yüzden yeni dönemde sadece bu iki seçkin cumhuriyet (Ukrayna ve Beyaz Rusya) ile birlikte olmak istediğini, Kazakistan Cumhurbaşkanı Nazarbayev'in girişimleriyle bunun Almatı Deklarasyonu’na dönüştüğünü hatırlatalım. Esasen Sovyetler Birliği döneminde de örneğin BM’de Ukrayna’nın özel temsilcisi bulunmakta olup, diğer cumhuriyetlere göre ayrıcalıklı bir durumda idi. RF- Ukrayna -özel- ilişkilerinin temelinde, her iki ülkenin (Beyaz Rusya ile her üç ülkenin) Slav kökenli olması, Ukrayna halkının önemli bir kısmının Ortodoks olması, yine etnik bakımdan nüfusun önemli bir kısmının Rus olması gibi tarihi, etnik, kültürel, dini ve jeopolitik birçok neden bulunmaktadır. Bu nedenlerle iki ülkenin işbirliği altyapısı oldukça güçlüdür. Buna karşın işbirliğinin güçlü olduğu alanlar aynı zamanda çatı̧manın gerekçesini oluşturabilmektedir. Ukrayna’ın jeopolitik yapısı, gerek AB gerekse NATO açısından son derece önemlidir. Esasen eski Sovyet cumhuriyetleri Litvanya, Letonya ve Estonya veya başta Karadeniz kıyıdaşı Bulgaristan ve Romanya gibi eski Varşova Paktı üyeleri için geçerli olan AB veya NATO üyeliği cazibesi (hem ülkeler hem de örgütler açısndan) Ukrayna açısından da önemlidir. Buna karşın Putin önderliğindeki Rusya Federasyonu, kendi nüfuz bölgesinde bu örgütlerin daha fazla genişlemesine müsaade edemeyeceğini her firsatta dile getirmiştir. Kırım’ın RF'na katılmasıyla 2014'de zirveye çıkan Ukryana-RF gerilimi aslında RF ile AB veya NATO 
çatışmasıdır. Moskova'nın Avrupa'yı kaybetme temelli bu çatışmada Ukrayna Rusya açısından direnç noktası olmuştur. 2017 itibariyle Kırım fiilen RF’nun parçası olup Ukrayna’nın RF sınır bölgelerindeki istikrarsızlık sürmektedir. Çatışma veya uzlaşmazlık boyutları son derece derin olan RF ve Ukrayna’nın coğrafi büyüklük, nüfus, askeri ve ekonomik kapasite bakımından KEİ’nin önde gelen üyelerinden olduğunu belirtelim.

KEİ’nin Karadeniz’e kıyıdaş olmayan iki kurucu üyesi Azerbaycan ve Ermenistan arasındaki savaş hali, aslında RF ile Azerbaycan veya RF ile bölgede nüfuz kurmak isteyen diğer güçler arasındaki çatışmadır. Daha SSCB dağılmadan Dağlık Karabağ’n bağımsızlık ilanı Sovyet organları tarafından reddedilmiş buna karşın sürekli Ermenistan lehine ve Azerbaycan aleyhine politikalar uygulanmıştır. Ocak 1990'da Dağlık Karabağ konusundaki Moskova politikalarını protesto eden Bakü'deki Azeriler, özel Rus birliklerince katledilmiş ve Azerbaycan tarihine Kara Ocak (Qara Yanvar) olarak geçmiştir. Bağımsızlı̆̆ın ilk yılları aynı zamanda Ermenistan-Azerbaycan savaşına sahne olmuş, bu savaş aslınde Rus askeri gücü dikkate alındığında Azerbaycan-RF çatışması olarak yaşanmıştır. Azerbaycan’ın ilk seçilmiş cumhurbaşkanı Ebulfez Elçibey'in RF karşıtı politikaları yüzünden RF’nun Azerbaycan'da iç isyanı kışkırtması sonucu Elçibey cumhurbaşkanlığını bırakmak zorunda kalmış ve Haydar Aliyev, Azerbaycan Cumhurbaşkanı olmuştur. Onun vefatından sonra da oğlu İlham Aliyev seçilmiştir. Aliyevlerin Moskova ile dengeli ilişkilerine karşın Dağlık Karabağ ile birlikte Azerbaycan’ın yaklaşık beşte biri üzerindeki Ermeni işgali devam etmekte olup sorun AGİT çerçevesinde MİNSK’te oluşturulan komisyona havale edilmiştir. RF bu komisyonun eşbaşkanlarındandır. RF, aynı zamanda Ermenistan ile askeri işbirliği çerçevesinde Azerbaycan topraklarındaki işgalin fiili yürütücüsüdür. Özellikle Türkiye’nin desteği ile KEİ’nin kurucu üyesi durumundaki Azerbaycan ve Ermenistan arasındaki çatışmada sık sık ihlal edilen ateşkes süreci yaklaşık çeyrek asırdır devam etmektedir. Bu durumdaki üyelerin yer aldığı KEİnin önemli kuruluş sorunlarından kurtulamaması son derece normal karşılanabilir.

Ermenistan, bağımsızlık deklarasyonunda Batı Ermenistan’ı (Doğu Anadolu) Ermenistan’n ayrılmaz parçası olarak kabul eder (Elekdağ, 2007). Daha sonra kabul edilen Ermenistan Anayasası’nın giriş kısmında ise, bu anayasanın Ermenistan Bağımsızlık Deklarasyonu’nu tanıdığı belirtilir. Soykırım iddialarının da baş aktörü durumundaki Ermenistan’ın mevcut sınırları tanımadığı her vesile ile gündemde tutulur. Anayasa ve deklarasyondaki iddialara karşın Türkiye ile Ermenistan arasında sınırları tanıma anlaşması imzalanmamış olup bu yüzden iki ülke arasında diplomatik ilişki kurulamamıştır. Mevcut sınırlar 1921 Moskova ve Kars anlaşmaları ile belirlenip o günkü Ermenistan Sovyet Sosyalist Cumhuriyeti meclisi tarafından onaylandığı halde Sovyet sonrası yönetim bunu tanımadığını deklare etmiştir. Ermenistan’n gerek Azerbaycan topraklarındaki işgalci pozisyonu gerekse Türkiye üzerindeki iddiaları, iki ülke sınır kapılarının açılmamasına neden olmuştur. Yine bu gerekçelerle gerek bugün işlemekte olan Bakü-Tiflis-Ceyhan petrol boru hattı ve gerekse Azerbaycan'dan Türkiye'ye diğer boru hatları ve ulaşım yolları Ermenistan üzerinden çok daha avantajlı olduğu halde ve bunda Ermenistan’ın da önemli kazancı olacağı kesin olduğu halde Erivan yönetimi ile uzlaşılamamış ve hatlar Gürcistan üzerinden kurulmuştur. Bu şartlar altında Erivan’ın Türkiye’nin öncülüğündeki KEİne kurucu 
üye olması önemli ölçüde Azerbaycan’a karşın RF’nun önerisi sonucudur. Bu durumda KEİ’nin uyumlu ve başarılı bir örgüt olması elbette beklenemez. Buna karşın aralarında diplomatik ilişki bulunmaya Ermenistan ile Türkiye ve Azerbaycan’n daimi sekreterliği İstanbul'da olan KEİ bünyesindeki ilişkilerin devam ettiğini ve Ermenistan’n sırası geldikçe dönem başkanlığını sorunsuz olarak yürüttüğünü belirtmeliyniz. Bu durumda çatışma halindeki komşuların aynı bölgesel örgütteki üyeliklerini devam ettirmeleri bizce KEİnin başarı hanesine yazılması gereken önemli bir husustur.

Karadenize kıyıdaş olmadığı halde Yunanistan’n KEİ üyesi olması, benzer durumdaki Arnavutluk'un üyeliğine RF’nun karşı önerisi olarak kabul edilmektedir. Belirtmek gerekir ki KEİ’nin kuruluş sürecinde Türkiye ile önemli sorunları bulunan gerek Ermenistan’n gerekse Yunanistan’n üyeliklerine Ankara ciddi bir şekilde karşı çımamış, bilakis bu üyelikler sayesinde mevcut sorunların daha sağlıklı bir şekilde çözülebileceğini hesap etmiştir. Türkiye ile Yunanistan arasında Ege Denizi alanında Karasuları, Kita Sahanlığı, FIR Hattı, Türkiyeye ait adaların Yunanistan tarafından fili işgali, gri bölgeler ile Yunanistan egemenliğindeki adaların silahlanması gibi sorunlar bulunmaktadır. Bunun yanında Kıbrıs sorunu da yarım asrı aşan bir süredir iki ülke arasında hiçbir zaman gündemden düşmeyen uzlaşmazlık konusudur. Bu sorunlar iki ülkeyi zaman zaman savaşın eşiğine getirmiş, 1974 Kıbrıs Barış Hareketi bir bakıma Yunanistan’ı da hedef almıştır. Batı Trakya Türklerinin durumu da zaman zaman ilişkilerin gerilmesine sebep olmaktadır. Aynı zamanda AB üyesi olan Yunanistan’n bir bakıma "tuzu kuru" olduğunu dikkate aldığımızda ekonomik işbirliği örgütü olarak KEİ’nin başarılı olmasının daha çok Türkiye’nin yararına olacağını hesap ettiği görülmektedir.

Kurucu üyeler arasında bir kısmına işaret edilen derin sorunlar, bazıları arasında zaman zaman sıcak çatışmaya dönüşen anlaşmazlıklar örgütün daha kuruluş aşamasında dinamizmini etkilemiştir. Belirtmek gerekir ki tıpkı AB’nin kuruluş sürecinde tarihi anlaşmazlık konusu Alsace-Lorene bölgesi üzerinde Almanyảnın hazmedemediği Fransa egemenliğine karşın her iki dünya savaşının mağlubu Almanya, hedeflerine örgüt içinde ulaşmayı hesap etmiştir. Bu hesap Fransảnın çıkarlarına da aykırı değildir. Esasen entegrasyon aşamaları, bu tür anlaşmazlıkları anlamsız kılacak, kazan kazan süreci işleyecektir. Türkiye, başta kendi ülkesine karşı tarihi iddia ve saldırıları sözkonusu olan ülkeler olmak üzere anlaşmazlık içinde olduğu komşularla KEI çerçevesinde ekonomik işbirliğine girmesi durumunda ortak çıkarların, tıpkı Fransa-Almanya örneğinde olduğu gibi, bu tür uzlaşmazlıkları bastıracağını hesap etmiştir.

KEİ’nin kuruluş sürecinde olmayan durum ise başta Almanya ve Fransa olmak üzere AB’nin kuruluş aşamalarının başında yer alan Avrupa Kömür ve Çelik Birliği ki bu ortaklık, bütün tarafların refahına katkıda bulunan bir bakıma ticari ortaklık benzeri işbirliği başlangıcıdır. Yani daha ilk aşamada politik veya ideolojik olmaktan çok fonksiyonal bir zemin sözkonusudur. Bu zeminde ilerleme sağlandıkça diğer aşamalara geçilmiştir. AB’ye üyelik sürecinde katılan devletler açısından komşularla veya mevcut üyelerle siyasi sorunları çözmüş olma gereği, birliğin bugüne kadar gösterdiği belirli bir başarıyı garanti etmiştir. Yani AB’ye üyelik öncesinde, ilgili devletler arasında siyasi sorunların çözülmüş olma şartı aranmaktadır. Örneğin Makedonyảnın üyelik 
sürecinde Yunanistan’ın itiraz ettiği "Makedonya" isim yerine "Eski Yugoslavya Makedonya Cumhuriyeti" ismini kabul etmesi, bu konudaki itirazlardan vazgeçmiş olması önemlidir.6 Benzer durum Sırbistan için de sözkonusu olup üyelik sürecinin başında Kosova ile sorunların çözülmesi şartı getirilmiştir. Bu yüzden Sırbistan Kosova konusunda önceki dönemlere göre daha uzlaşmacı yola girmiştir. KEİ’nin kuruluş aşamasında ise mevcut ikili veya üçlü sorunların çözülmesi yerine önce örgütün kurulması, örgüt çatısı altında sorunların çok daha kolayca, belki kendiliğinden çözüme ulaşacağı beklentisi sözkonusu olmuştur.

\section{Karadeniz ve Hinterlandında İşbirliği Zorunluluğu / Karadenizin Jeopolitiği}

Yukarıda işaret edildiği gibi KEİ coğrafyasındaki ülkeler önemli ölçüde diğer uluslararası örgütlere de üyedir. Asya, Avrupa, Kafkasya, eski Doğu Bloku üyeleri, eski Sovyet cumhuriyetleri gibi alt bölgeler açısından bakıldı̆̆gnda belirli gruplaşmalar sözkonusudur. Bu kapsamda örneğin Yunanistan, Bulgaristan ve Romanya, AB üyesi ${ }^{7}$; bütün üyeler amaçları arasında ekonomik işbirliği de bulunan Avrupa Konseyi üyesi; başta RF olmak üzere Azerbaycan, Ermenistan ve Moldova, BDT üyesi (Ukrayna ve Gürcistan BDT'den ayrılmışlardır); Türkiye ve Azerbaycan, ECO üyesi; Azerbaycan, Gürcistan, Ukrayna ve Moldova, GUAM üyesidir. Bu yönüyle KEİ, bir bakıma komşu örgütlerin bileşkesi durumundadır. Bu bağlamda Bakü merkezli uluslararası örgüt statüsü kazanmış olan TRACECA’ya Arnavutluk, Rusya, Sırbistan ve Yunanistan dışındaki devletler üyedir. "Karadeniz" ile başlayan BLACKSEAFOR (Karadeniz Donanma İşbirliği Görev Grubu) da Türkiye’nin öncülüğü ile doğrudan Karadeniz kıyıdaşı altı ülkenin 2001'de oluşturduğu bir örgütlenmedir. ${ }^{9}$ Bu girişim, kıyıdaş ülke donanmalarının başta Karadeniz'de arama-kurtarma faaliyetleri olmak üzere barışçıl amaçlarla ortak hareketlerini öngörmektedir (Ulusoy, 2002).

Kurucu veya sonradan katılan üyeler dikkate alındığında üyelerin tamamının diğer önde gelen üyelerle önemli örgütlerde birlikte yer aldıkları görülmektedir. Esasen aynı anda başka örgütlerdeki üyeliğin devamı bazı yönleriyle $\mathrm{AB}$ de dahil hemen bütün uluslararası kuruluşlar için sözkonusudur. Bununla beraber Karadeniz bögesi, Avrupa ve Asya örgütlerine üye devletlerin kesişim alanı durumundadır. Bu kesişme önemli ölçüde Türkiye üzerinden gerçekleşmiştir. Bu anlamda Balkanlar, Karadeniz, Kafkasya ülkesi olarak Türkiye çevresinde işbirliği zemini bütün bölge ülkeleri açısından bir bakıma jeopolitik zorunluluk veya coğrafyanın zorunlu kıldığı bir

Güney Kıbrıs Rum Yönetimi’nin aday ülke Türkiye ve KKTC ile son derece kapsamlı uzlaşmazlıklarına karşın üyeliğe kabul edilme süreci, AB’nin Hıristiyan klübü olduğu iddiaları veya batının bilinçaltında yer alan Türkofobi kapsamında değerlendirilmelidir.

7 KEİ'nin kuruluş aşamasında Romanya ve Bulgaristan henüz AB üyesi olmadıkları halde, bu ülkeler 2007'de birliğe katılmışlardır.

8 Yeni İpek Yolu olarak da bilinen bu örgütleşmenin siyasal önemi konusunda bkz.: Archil Gegeshidze, “The New Silk Road: A Georgian Perspective”, Perceptions, June-Augusst 2000; 132-140. TRACECA-KEİ ilişkileri için ayrıca bkz.: Alaeddin Yalçınkaya, "TRACECA as a European Organisation”, 6. Silk Road International Conference: Globalization and Security in Black and Caspian Seas Regions, Tbilisi-Batumi, Georgia, 2011, ss. 34-42, http://silkroad.ibsu.edu.ge/ previous/sixth/5_02.pdf, erişim tarihi: 15.11.2016

9 Karadeniz Deniz İşbirliği Görev Grubu Teşkiline Dair Anlaşma, https://www.dzkk.tsk.tr/icerik.php?icerik_ id=248\&dil=tr\&blackseafor $=1$ erişim tarihi: 15.11 .2016 
politikadır. Bu işbirliğinin konusu ticaret, sanayi, ulaştırma, turizm ve genel olarak ekonomi olduğu gibi siyaset boyutu da sözkonusudur. Çünkü bu bölgedeki siyasi işbirliği, sömürülen veya azgelişmiş ülkeler üzerindeki politikaları derinden etkileyecektir. Genel olarak eski sömürge veya doğu toplumlar üzerinde sürüdürülmekte olan "böl-yönet" uygulaması bir kısmı yukarıdaki çatışma örneklerinde de kendisini gösteren "karıştır-kontrolü elinde tut" kuralıyla yürütülmektedir. Siyasi işbirliğinin ekonomik refahı desteklemesi gibi ekonomik entegrasyon ile sinerji kazanacak olan zenginlik, siyasi uzlaşmaları da peşinden sürükleyecektir. Eski sömürgeci Batı Avrupa devletleri veya ABD’nin kendi kontrolleri dışındaki bu gelişmeyi desteklemeleri veya buna seyirci kalmaları elbette beklenemez.

Karadeniz jeopolitiğinin Uluslararası Hukuk alanında somutlaştığı son derece önemli belge 1936 Montreux Boğazlar Sözleşmesi'dir. Bu sözleşme Karadeniz kıyıdaşı ülkelere önemli ayrıcalıklar vermekte olup örneğin kıyıdaş olmayan ülkelerin Karadeniz’de donanma bulundurmalarına önemli kısıtlamalar getirmektedir. Buna göre kıyıdaş olmayan bir ülkenin gemisi Karadeniz’de en fazla üç hafta kalabilmektedir. Bu sözleşmenin bir sonucu olarak bugün ABD’nin uçak gemisi olmayan tek denizin Karadeniz olduğunu hatırlatalım. Bu gerçekten dolayı ABD, Montreux'yü kendi lehine değiştirmek isterken başta RF olmak üzere Karadeniz ülkeleri bu sözleşmeye sahip çımaktadır. Azak Denizinden Marmara, Boğazlar ve Ege Denizi’ne kıyıdaş veya hinterlant ülkelerinin ortak bir örgütte işbirliğine gitmeleri, belgelerde açıç̧a belirtilmemiş olmakla birlikte ortak savunma veya bölgesel dayanışmanın gereğidir. Bunun yanında ortak coğrafyanın gerektirdiği ekonomi boyutu da bulunmaktadır ki başta $\mathrm{AB}$ olmak üzere bölgesel ekonomik örgütlerin temel mantığı da buna dayanmaktadır.

KEİ üyelerinin enerji, gıda, eğitim, teşebbüs gibi alanlarda önemli ölçüde tamamlayıcı olması da bu örgütü fonksiyonal kılmaktadır. Bu bağlamda RF ile Azerbaycan önde gelen enerji ihracatçısı ülkeler olup diğerleri ithalatçı veya geçiş yolu ülkeleridir. Gürcistan, Türkiye ve Balkan ülkelerinin enerji yolları üzerinde olması bu anlamda işbirliğini gerektirmektedir. Yukarıda belirtildiği gibi Azerbaycan petrolünün Ceyhan’a ulaştırılmasında daha kısa yol olan Ermenistanın kullanılamaması bu hattın daha pahalıya olması yanında KEİ içinde en fakir ülkelerden olan Ermenistan için de büyük kayıp olmuştur. Ermenistanın bugün açıkça Azerbaycan ve Türkiye’ye karşı, bir aşama sonra Jevehati üzerinden Gürcistan’a karşı, kısaca hepsi KEİ üyesi komşularına yönelik yayılmacı politikası elbette başarısız kalmaya mahkumdur. Ancak bu süreçte Ermenistan halkının sıkıntıları, hatta son çeyrek asırda benzeri olmayan bir şekilde nüfusu azalan, yok olan bir ülke durumuna gelmesi bu ülkenin komşularıyla barış, dostluk ve güvene dayalı işbirliği yapmamasından dolayı kayıplarını ortaya koymaktadır. Netice itibariyle çatışma politikalarının zararını halk çekmektedir. Ancak bu politikaları halkın gerçekten onayladığı ise tartı̧malı olup önemli ölçüde başka ülkelerinin baskısı ile (başta ABD ve Fransa’daki Ermeni diyasporası) Ermenistan, özellikle iki Türk komşusu ile uzlaşmazlık tercihini sürdürmektedir.

Sovyetler Birliği’nin dağılmasından sonra devletçi ekonomiden liberal ekonomik düzene geçmek zorunda kalan eski Sovyet cumhuriyetleri ile Varşova Paktı üyelerinin yeni döneme adaptasyonu ve uluslararası ekonomiye uyum sağlamaları son derece sancılı olmuştur. Örneğin mevcut Rus 
oligarkların önemli bir kısmı bu sancılı dönemin fırsatçıları olarak ortaya çıkmıştır. Uluslararası finans, yatırım, ticaret, müteahhitlik, nakliye gibi birçok alanda Türkiye ve Yunanistan'ın devletçi ekonomiden gelen diğer üyelerle önemli işbirliği alanları bulunmaktaydı. Esasen KEİ Şartı’nın giriş kısmında serbest ekonomiye geçiş gerekliliğinin paylaşıldığı özellikle belirtilmiştir. ${ }^{10}$

\section{Türkiye-Rusya Federasyonu}

Örgütün daha kuruluş aşamasında, RF önderliğindeki BDT’na rakip bir oluşumun sözkonusu olmadığı her fırsatta dile getirilmiştir. Üye ülkeler içinde gerek coğrafya ve nüfus gerekse ekonomik ve askeri büyüklük bakımından RF birinci durumdadır. Bununla beraber Soğuk Savaş döneminin süper gücü olarak SSCB, 1990ların başında dağılmış ve yıllarca RF’nun dağılma endişesi, özellikle 1990lar boyunca bölgeyi meşgul etmiştir. Ekonomik, sosyal, idari ve hukuksal bakımdan kriz dönemi yaşayan RF'nun KEİ gibi bir bölgesel işbirliği örgütlenmesine gitmesi öncelikle yeni döneme adapte olmanın zorunlu kıldığı bir politikadır. Bununla beraber rakip durumundaki Türkiye ile ekonomik avantajlarını paylaşmak hatta bunları kaptırmak kaygısı Rus stratejistleri meşgul etmiştir. ${ }^{11}$

Türkiye-Rusya kutupları yukarıda ele alındığı üzere örgüt içindeki örneğin RF-Gürcistan, RFUkrayna, Azerbaycan-Ermenistan benzeri çatışma ilişkilerine de yansımıştır (Elekdağ,1997). Bununla beraber bu gibi krizler örgütün faaliyetlerini etkilememesi yönündeki siyasi irade, daima baskın çıkmıştır. Belki de bunun en önemli göstergesi Azerbaycan ülkesinin yaklaşık beşte biri Ermenistan işgalinde bulunmasına ve halen Ermenistan, Türkiye ile mevcut sınırları tanıma anlaşmasına yanaşmamasına, bu gibi sebeplerden dolayı Türkiye ve Ermenistan arasında diplomatik ilişkilerin kurulmamasına karşın, yukarıda da belirtildiği üzere Ermenistan’ın KEİ üyeliği ve sırası geldikçe dönem başkanlığı konususunda sorun yaşanmamasıdır.

Türkiye ve RF arasındaki bir kısmına işaret edilen siyasi cepheleşmeye karşın birinin ekonomisi önemli ölçüde enerji ihracına dayanırken diğeri enerji ithalatçısı bu iki ülkenin aynı örgütleşmenin öncüleri olması bu açıdan anlamlıdır. Öyleki 2015’te yaşanan uçak krizinden sonra Türkiye’ye gönderilen turist, Türk müteahhitlerin Rusya'daki yatırımları ve Türkiye'den sebze-meyve ihracına engeller konulurken RF’nun Türkiye'ye doğalgaz satışında bir aksama olmamıştır. Türkiye’nin bu konudaki telafi edilmez ihtiyacı kadar Rusya’nın da ekonomik ve stratejik zorunlulukları bu satışı sürdürmeyi zorunlu kılmıştır. Türkiye’nin mevcut altyapı imkanları dikkate alındığında Rus doğalgazına olan ihtiyacı yanında, Rusyảnın mevcut uluslararası ortamda en iyilerden biri durumundaki doğalgaz müşterisini kaybetme lüksü yoktu. Hem RF’nun hem de Türkiye’nin şiddetle ihtiyaç duyduğu bu ve benzeri konulardaki işbirliği gerçeği aynı zamanda bölgesel örgütleşmenin somut alyapı unsurlarından birini oluşturmaktadır.

10 Charter of the Organization of the Black Sea Economic Cooperation

11 Örneğin Dugin, 1990'larda NATO üyesi olarak Türkiye ile yakınlaşmanın RF için sakıncalı olduğunu söyler; Aleksandr Dugin, Rus Jeopolitiği, Avrasyacı Yaklaşım, terc.: Vügar İmanov, 4. Basım, İstanbul, Küre Yayınları, 2005. 
Türkiye'de yaşanan 2015 darbe girişimi ve Suriye'deki gelişmeler iki ülkeyi yeniden yakınlaştırmış, uçak krizi sonrası kopukluk kalıntıları önemli ölçüde telafi edilmiştir. Daha da önemlisi bu dönemde $A B$ ile yaşanan sorunlar sonucu Türkiye'nin $A B$ adaylık sürecindeki kaygıları artmış, bunun yerine Şanghay İşbirliği Örgütü’ne üyelik yeniden dillendirilmiştir. Bu aşamada Çin’den ve RF’ndan olumlu mesajlar gelmiştir. Belirtmek gerekir ki Şanghay İşbirliği Örgütü, AB’nin alternatifi olmayıp bunun yerine örneğin RF önderliğindeki Avrasya Ekonomik Birliği alternatifi ortaya konsa daha anlamlı olabilirdi. Bununla beraber Şanghay İşbirliği Örgütü’nün zikredilmesi ile batıya verilen “Türkiye’yi kaybediyorsunuz” mesajı sözkonusu olabilir ki AB’nin önde gelen devletleri Türkiye’nin üyeliğine sıcak bakmadıkları halde adaylık statüsünde oyamalayı, ilişkileri bu çerçevede canlı tutmayı tercih etmektedirler. Bu bağlamda adaylık süreci çerçevesindeki ilişkileri noktalamış bir Türkiye, $\mathrm{AB}$ açısından son derece sakıncalıdır. Bütün bunlara karşın, Tükiye’nin KEİne işlerlik kazandırmak, örneğin şartta da belirtildiği üzerek KEİ Serbest Ticaret Bölgesi'nin kurulması için harekete geçmek gibi bir beyan sözkonusu olmamıştır. Türkiye’nin böyle bir girişimi halinde örneğin Azerbaycan, Gürcistan, Arnavutluk gibi ülkelerle Serbest Ticaret Bölgesi kurması kısa zaman içinde mümkün olabilecektir. Bu bağlamda Avrasya Ekonomik Birliği+KEİ çerçevesinde daha iler entegrasyon aşamalarına geçilebilir. Ancak KEİnin hiçbir şekilde zikredilmemiş olması, bu örgütün başarısı/başarısızlı̆̆ı açısından önemli bir kıstastır. Belki de Türk Dış Politikası’nda bir hata olarak değerlendirilebilecek KEİni bir bakıma unutmadir.

\section{KEI’nin Bölge Politikalarındaki Yeri}

Kuruluş sürecinde özellikle ekonomik ve sosyal alanda bölgesel işbirliği konusunda iddialı olan KEİ’nin, yaklaşık 20 yıl sonra bu hedefleri doğrultusunda dikkat çeker faaliyetleri oldukça sınırlıdır. 1992 Boğaziçi Belgesi’nde Sovyet sonrası şartların sebep olduğu krizlerin sosyoekonomik alanlardaki iyileşme ve işbirliği ile aşılacağına işaret edilmekte idi. Geçiş döneminin siyasi olduğu kadar etnik ve güvenlik sorunlarının ancak bu işbirliği ile aşılacağı umulmaktaydı. İnsan hakları yanında örneğin çevresel sorunların da çözümünün bütün üye ülkelerin çıarına olacağı vurgulanmıştır. Bu tür sorunların çözümü ve sosyal, ekonomik ve hukuksal anlamdaki iyileşme ile ulaşılacak refah toplumunun dünya ekonomisi ile entegrasyonu daha başarılı olacağı beklentisi oldukça yüksekti.

Ticari alanda kuruluşların işbirliği, diğer üye ülkelerde yatırımların teşviki yönünde kolaylaştırıcı düzenlemeler bulunmakta olup bu kapsamda çifte vergilendirmenin önlenmesi hükmü şirketler açısından önemlidir. Öte yandan bölgesel yatırımlar için gerekli finansal kaynak sağlanması konusunda uluslararası kuruluşlardan destek almak için gerekli altyapının oluşturulması da örgütün gündemindedir. Bu bağlamda Karadeniz Dış Ticaret ve Yatırım Bankası’nın kurulması niyeti daha Boğaziçi Deklarasyonu’nda dile getirilmiş ve 1994 Tiflis Zirvesi ile bankanın kuruluşuna karar verilmiştir. ${ }^{12}$ 1998'e gelince sözkonusu banka Selanik’te kurulmuştur. 2016 yılı itibariyle yaklaşık 4.2 milyar dolarlık bir kaynağı yöneten bankanın mesela 2015’te desteklediği

12 Summit Declaration on Black Sea Economic Cooperatin, İstanbul (25 Haziran 1992). 
yatırımlar dikkate alındığında KEİnin belki de bölge politikaları çerçevesinde en somut etkinliği olarak görülebilir. Desteklenen projeler konusunda bütün üyeler arasında dengeli bir dağılımın sözkonusu olması da dikkate alınması gereken başarı unsurudur. ${ }^{13}$

1997 İstanbul Deklarasyonu ile KEİ Serbest Ticaret Bölgesi kurulmasının nihai hedef olduğu dile getirilmiştir. ${ }^{14}$ Bölgesel işbirliği açısından son derece önemli olan bu konudaki niyet beyanı dahi bölgesel politikaları kökten değiştirecek nitelikte olduğu halde geçen süre zarfında bu konuda niyetten uygulamaya geçişte bir adım atılmamıştır.

2016 sonu itibariyle ECO, CICA, D-8 ve benzeri örgütler için olduğu gibi KEİ için de başarısız demek anlamsız bir yargıdır. Kuruluş sürecinin başlamasından yaklaşık çeyrek asır sonra böyle bir yargılamadan önce kurucu üyelerin gerçek amaçları ile bu amaçların ne kadar gerçekçi olduğunu sorgulamak gerekmektedir. Örgütün kurucu 11 üyesinden (Arnavutluk, Azerbaycan, Bulgaristan, Ermenistan, Gürcistan, Moldova, RF, Romanya, Türkiye, Ukrayna ve Yunanistan) hiçbirinin örgütten ayrılma eğilim sözkonusu olmadığı gibi 2004 yılında Sırbistan da bu örgüte üye olmuştur. ${ }^{15}$ Bir kısmı kuruluş aşamasında olmak üzere Avusturya, Belarusya, Hırvatistan, Çek Cumhuriyeti, Mısır, Almanya, İsrail, İtalya, Polonya, Slovakya, Tunus, ABD ile International Black Sea Club, Energy Charter Secretariat, Black Sea Commission, Commission of the European Union adlı örgütler KEİ’ne gözlemci üye durumundadır. ${ }^{16}$ Ayrıca birçok devlet veya uluslararası örgütün KEİ ile "Sektörel Diyalog Ortaklığı" bulunmaktadır. Örneğin BDT’nun kurucu üyesi durumundaki bazı ülkeler BDT’undan ayrılmış, bazen yeniden üyelik ve üyelikten çıkma gibi süreçler yaşandığı halde KEİ için böyle bir durum sözkonusu olmamıştır. ${ }^{17}$ Bu bağlamda KEİ’nin üyelik ilişkilerini ve diğer aktörlerle diplomatik bağlarını güven içinde ve başarıyla koruduğunu belirtmek gerekmektedir.

\section{Sonuç}

Daimi sekretaryalığı için İstanbul Boğazı kıyısında, Müşir Fuat Paşa Yalısı'nın tahsis edildiği KEİ, kuruluşundan günümüze birçok uluslararası örgütte yaşanan örneğin üyelik veya dönem başkanlığı benzer bir sorun yaşamamıştır. İlginçtir ki Türkiye ile Ermenistan arasında diplomatik ilişkiler bulunmadı̆̆ 1 halde örgütün kurucu üyesi durumundaki Ermenistan temsilcisi sırası geldiği zaman bu yalıdan dönem başkanlığını yürütmektedir.

Birçok örgüt için sözkonusu olduğu gibi KEİ’nde de merkez ülkelere baktığımızda ekonomik, siyasi ve askeri gücü belirli bir düzeyde olan ülkeler Türkiye, RF ve Ukrayna’yı görmekteyiz. Bölgesel güç olarak Türkiye ile RF’nun birçok bakımdan rekabetinin veya nüfuz çatışmalarının

13 Black Sea Trade and Development Bank, 2015 Annual Report http://www.bstdb.org/publications/BSTDB_Annual_Report_2015.pdf, erişim tarihi: 10.11.2016

Declaration of Intent For The Establishment of the BSEC Free Trade Area (7 Şubat 1997).

15 Contracting Parties, http://www.bsec-organization.org/documents/LegalDocuments/statutory/charter/Pages/ charter.aspx, 10.11.2016 
örgüt faaliyetlerine yansıması mümkündür. Bunun ötesinde özellikle 2014'de yaşanan gelişmelerden sonra RF ile Ukrayna arasındaki sorunların örgütün faaliyetlerini olumsuz etkilemediği söylenemez. Bununla beraber bu iki ülke arasında sorunların olmadığı döneme göre KEİ’nin ciddi bir şekilde gerilemiş olan faaliyet alanı bilinmemektedir.

2017 başı itibariyle KEİ, kuruluşundan günümüze geçen süre içinde arzu edilen başarıyı gösterememiş, örneğin üye ülkelerin herbiri diğer üye ülke vatandaşlarına karşı vizeleri kaldıramamışlardır. Bunun yanında ekonomik işbirliği açısından son derece önemli olan çifte vergilendirmenin önlenmesi konusuda ortak politikalar oluşturulamamıştır. Öte yandan yatırımların teşviki, desteklenmesi ve korunması konusunda da gerekli anlaşmalar henüz imzalanmamış, altyapı oluşturulamamıştır (Karluk,2014: 549). Bu bağlamda başarısız uluslararası kuruluşların doğal olarak dönüşüme girmesi veya tasfiye sürecine girmesi kaçınılmazdır (Al, 2016: 30). Bu gerçekler ışığında KEİ’nin 2017 zirvesinde bir dönüşüm sürecine gireceği beklenmektedir.

KEİ'nin kuruluş sürecinde hem NATO hem de AB üyesi olan tek üye Yunanistan genellikle Rusyảnın yanında Türkiye’nin karşısında yer almıştır. Burada bir yönüyle tarih boyunca olduğu gibi Ortodoks dayanışması izlenmiş, siyasi veya ideolojik tercihler, ekonomik olanların önüne geçmiştir. Bu anlamda iki ülke arasındaki mezhepsel yakınlık veya Rusya ile tarihi stratejik işbirliği, KEİ faaliyetlerine de yansımıştır.

Türkiye’nin kendi imkânları dikkate alındığında büyük fedakârlık gösterdiği kuruluş aşamasında, şüphesiz Soğuk Savaş sonrası şartlarını kendi çıkarları istikametinde değerlendirme hedefi sözkonusudur. 1980'lerde başlayan dünya ekonomisi ile birleşme yönündeki hedefler istikametinde 1990 'larda artan üretim ve müteahhitlik hizmetlerine yeni pazarlar bulma ihtiyacı ortaya çıkmıştır. Bu şartlar altında eski Doğu Bloku coğrafyası bu bakımdan geniş bir alan olduğu halde devletçi ekonominin çökmesi sonucu liberal kurallar henüz yerleşmemişti. Bu açıdan sözkonusu ülkelerle ticaret veya yatırım kârlı olduğu kadar riskli bir durum arzetmekteydi. Bundan dolayı Türkiye’nin kendi üreticisi veya yatırımcısına güvenilir pazarlar oluşturma arzusu KEİ için yapılan fedakârlıkların gerekçelerinden kabul edilir. ${ }^{18}$

KEİ’nin 20. Ylldönümü Zirvesi, 26 Haziran 2012'de İstanbul'da düzenlenmiştir. Bu zirvede, örgütün kuruluşunun 25. Yllı vesilesi ile 2017'de yapılacak zirve toplantısının yine İstanbul'da, Türkiye’nin dönem başkanlığında yapılması kararlaştırılmıştır. Türk Dışişleri Bakanlığı, sözkonusu 2017’deki toplantıda "KEİ'de reform sürecine gidilmesi ve örgütün daha etkin, verimli ve sonuç odaklı çalışması yönünde çaba sarfedilecektir" duyurusunu 2012 yılında yapmış olması, aslında örgütün beklenen etkinliği göstermediği anlamına gelmektedir. ${ }^{19}$ 2017'deki zirvede ise başta vize ve çifte vergilendirme konusu olmak üzere yatırımların teşviki, desteklenmesi, korunması gibi konularda kapsayıcı sözleşmelerin imzalanması beklenmektedir.

18 KEİ üyeleri arasındaki ticari ilişkiler konusunda bkz.: Alaeddin Yalçınkaya, Kafkasya'da Siyasi Gelişmeler: Etnik Düğümden Küresel Kördüğüme, Ankara, Lalezar Kitabevi, 2006, ss.253-282

19 Karadeniz Ekonomik İşbirliği Örgütü (KEİ), http://www.mfa.gov.tr/karadeniz-ekonomik-isbirligi-orgutu-_kei_. tr.mfa 15.11.2016 


\section{Kaynakça}

Al Arzu, (2016) "Ekonomik (Finansal) Krizin Kavramsal Çerçevesinin Küresel Yönetişim Açısından Değerlendirilmesi”, Uluslararası Politik Ekonomi, Ekonomik Krizler ve Türkiye, A. Al (ed.), İstanbul: BKY, 13-32.

Black Sea Trade and Development Bank, (2015) Annual Report, http://www.bstdb.org/publications/ BSTDB_Annual_Report_2015.pdf, Erişim Tarihi: 10.11.2016

Charter of the Organization of the Black Sea Economic Cooperation, http://www.bsec-organization.org/ documents/LegalDocuments/statutory/charter/Download/CHARTER\%20web\%20080630.pdf Erișim Tarihi: 10.11 .2016

Contracting Parties, http://www.bsec-organization.org/documents/LegalDocuments/statutory/charter/ Pages/charter.aspx, Erişim Tarihi: 10.11.2016

Declaration of Intent For The Establishment of the BSEC Free Trade Area, 7 Şubat 1997, http://www. pabsec.org/depo/documents/reports-and-recommendations/en-rec-rzrrl1rggw.pdf Erişim Tarihi: 24.11.2016

Dugin Aleksandar, (2005) Rus Jeopolitiği, Avrasyacı Yaklaşım, terc.: Vügar İmanov, 4. Basım, İstanbul: Küre Yayınları.

Elekdağ Şükrü, (5 Mayıs 1997) Milliyet.

Elekdağ Şükrü, (Mart 2007) “Şamar Oğlanı Haline Düşürlen Türkiye”, Yankı Dergisi, https://sukruelekdag. wordpress.com/category/makaleler/page/9/ Erişim Tarihi: 07.01.2017

Functionalism, http://www.worldlibrary.org/articles/functionalism_(international_relations), Erişim Tarihi: 07.01.2017

Gegeshidze Archil, (2000) “The New Silk Road: A Georgian Perspective”, Perceptions, (June-August): 132140.

Jusufovic Sejla, (14 Mayıs 2013) “Turkey-Black Sea Economik Cooperation (BSEC) Relation” Uluslararası Politika Akademisi, http://politikaakademisi.org/2013/05/14/turkey-black-sea-economiccooperation-bsec-relations/ Erişim Tarihi: 15.11.2016

Karadeniz Deniz İşbirliği Görev Grubu Teşkiline Dair Anlaşma, https://www.dzkk.tsk.tr/icerik.php?icerik_ id=248\&dil=tr\&blackseafor=1 Erişim Tarihi: 15.11 .2016

Karadeniz Ekonomik İşbirliği Örgütü (KEİ), http://www.mfa.gov.tr/karadeniz-ekonomik-isbirligi-orgutu-_ kei_.tr.mfa Erişim Tarihi: 15.11.2016

Karluk Rıdvan, (2014), Küreselleşen Dünyada Uluslararası Kuruluşlar, Yedinci Baskı, İstanbul: Beta.

Nureș Nurver, (1998) „Karadeniz Ekonomik İșbirliği Konseyi Kurulușu, Hedefleri, Faaliyetleri Hakkında Belgeler“, Türk Cumhuriyetleri ve Petrol Boru Hatları, der.: Alâeddin Yalçınkaya, İstanbul:Bağlam, 193-214.

Mehmetçik, Hakan, Hakan Mehmetçik, "Küresel Ekonomik Krizler ve Türkiye’nin G20 Algısının Dönüşümü”, Uluslararası Politik Ekonomi, Ekonomik Krizler ve Türkiye, Arzu Al (ed.), İstanbul, BKY, 2016, ss. 37-58.

Observers, http://www.bsec-organization.org/partners/Pages/Observers.aspx Erişim Tarihi: 10.11.2016

Organization of Democracy and Economic Development, http://guam-organization.org/en/node/422 Erișim Tarihi: 10.11.2016

Sezer, Duygu Bazoğlu, "Evolving Balances in the Black Sea Region", Seminer on Russia and the Nis, Minutes, 29-31 Mart 1996, Ankara, Sam Papers No: 1/96; ss.48-52.

Summit Declaration on Black Sea Economik Cooperation, http://www.bsec-organization.org/documents/ declaration/summit/Reports/Istanbul1992.pdf Erişim Tarihi: 08.11.2016 
Ulusoy, Hasan, "A New Formation in the Black Sea: BLACKSEAFOR” Perceptions, Dec. 2001-Feb. 2002.

Yalçınkaya, Alaeddin, "TRACECA as a European Organisation”, 6. Silk Road International Conference: Globalization and Security in Black and Caspian Seas Regions, Tbilisi-Batumi, Georgia, 2011, ss. 3442, http://silkroad.ibsu.edu.ge/previous/sixth/5_02.pdf, Erişim Tarihi: 15.11.2016

Yalçınkaya, Alaeddin, Kafkasya’da Siyasi Gelişmeler: Etnik Düğümden Küresel Kördüğüme, Ankara, Lalezar Kitabevi, 2006, ss.253-282. 